\title{
Indicators of the internal organs weight of purebred and crossbred young sheep with different methods of fattening
}

\author{
D. Byamba ${ }^{1}, S$. Biltuev $^{1}, V$. Achituev $^{1}, B$. Zhamyanov $^{1, *}, A$. Biltuev $^{2}$ \\ ${ }^{1}$ FSBEI HE "Buryat State Agricultural Academy named after V.R. Filippov", 8 Pushkina Street, Ulan- \\ Ude, 670034, Republic of Buryatia, Russia \\ ${ }^{2}$ FSBSI "Buryat Scientific Research Institute of Agriculture", 25"z" Tretyakova Street, Ulan-Ude, \\ 670045, Republic of Buryatia, Russia
}

\begin{abstract}
The article presents the results of studies of the indicators of live weight and the internal organs weight of purebred Khalkha and crossbreed Khalkha-Suffolk rams, depending on the method of their fattening. Experimental studies were conducted in the Selenga aimak of Mongolia and in the laboratories of the Mongolian University of Natural Sciences. According to the results of the research, it was revealed that purebred Khalkha rams were inferior to Khalkha-Suffolk crossbreed rams in terms of live weight at birth and at the age of 8 months. When fed with rapeseed cake, purebred Khalkha rams had an advantage over half-breeds in terms of absolute heart weight by $0.04 \mathrm{~kg}$ and digestive system weight by $0.06 \mathrm{~kg}$, and in terms of pre-slaughter weight by 0.22 and $1.29 \%$, respectively. At the same time, Khalkha-Suffolk crossbreed rams outperformed purebred animals in terms of absolute lung weight by 0.19 $\mathrm{kg}$ and relative weight by $0.19 \%$.
\end{abstract}

\section{Introduction}

The extensive use of the internal organs of domestic animals as food is an important strategic resource of humanity in dietary protein provision. According to the traditional customs of the nomads of Mongolia, all organs and by-products from 5 animal species (horses, camels, cattle, sheep and goats), except for the respiratory organs, are used by humans. In farm animals, the energy expenditure of the internal organs accounts for the main share of the expenditure on the basal energy of metabolism. According to the FAO, about $30 \%$ of the main energy expenditure is the result of the metabolism of gastrointestinal tract, liver and heart, and an additional $22 \%$ is accounted for by the kidneys, skin and brain $[11,9]$.

According to statistics for 2019, there were 70969.3 thousand heads of cattle in Mongolia, including 32267.3 thousand sheep [14]. At the same time, meat production and supply reflect the amount of whole meat, but do not take into account the resources and consumption of internal organs, such as the heart, liver, kidneys, etc. In Mongolia, there is

* Corresponding author: bair1717@mail.ru 
not enough scientific research on the weight characteristics of internal organs under different conditions of sheep raising. The purpose of this study is to determine the effect of top dressing with rapeseed cake during feeding on the indicators of live weight and weight of internal organs of purebred and crossbred young animals. The research objectives were to study the effect of feeding young animals of different breed groups with rapeseed cake during fattening:

1. on live weight indicators

2. on internal organs weight.

Data from measurements of the internal organs of young sheep of the Khalkha breed and Khalkha-Suffolk crossbreeds make it possible to determine the potential possibilities of their use in the food industry of the Mongolian People's Republic.

\section{Material and research methods}

Studies on the weight indicators of carcass and internal organs of young rough-haired Khalkha sheep and half-blooded Khalkha-Suffolk crossbreeds during their fattening were carried out in the Arvin Hur farm of the Selenga aimak and in the laboratories of the Mongolian State Agrarian University according to the scheme developed by the authors [1]. To conduct research, three groups of 5 heads each, born on the same day, were formed from purebred and crossbred young stock of the Khalkha breed. Lambs - rams of the first and second groups were represented by the Khalkha breed, and the third - by half-blood Khalkha-Suffolk crossbreeds (F1). Lambs of all groups from birth to 1.5 months were grown without supplementary feeding. After reaching 1.5 months, the young animals of the second and third groups, in addition to mother's milk and pasture grass, received "plenty" of rapeseed cake. At the same time, animals of the second group aged from 1.5 to 3 months on average per head per day ate $74.3 \mathrm{~g}$ of cake/day, from 3 to 8 months - $183.8 \mathrm{~g}$ of cake/day; animals of the third group - 101.8 and $218.5 \mathrm{~g}$ of cake/day, respectively. The young animals of I group were grazed on natural pastures during the entire fattening period. The live weight of lambs of the I, II and III experimental groups at birth was $3.40 \pm 0.15 ; 3.31 \pm 0.11$ and $4.68 \pm 0.63 \mathrm{~kg}$, respectively, at the age of 1.5 months $-6,83 \pm 0,95 ; 6,57 \pm 0,57 ; 9,90 \pm 0,70$ $\mathrm{kg} ; 3$ months $-14,57 \pm 2,05 ; 16,77 \pm 1,40 ; 18,77 \pm 1,90 \mathrm{~kg}$, and 8 months $-32.43 \pm 3.59 \mathrm{~kg}$, the second $-38.0 \pm 2.45$ and the third $-48.2 \pm 1.93 \mathrm{~kg}$.

In the presented work, absolute weight indicators of carcass, internal organs and digestive system were studied according to approved methods [2,9]. Relative indicators of carcass weight, internal fat, liver, kidney, heart, lungs, spleen, and gastrointestinal organs were studied in relation to the live weight (pre-slaughter) of young animals of the experimental groups.

\section{Research results and their discussion}

After fattening, the pre-slaughter live weight was the highest in crossbred rams $-45.10 \mathrm{~kg}$ and the lowest in the first group of the Khalkha breed $-30.47 \mathrm{~kg}$. Satisfactory indicators of live weight after fattening of young animals of the Khalkha breed (group I) on natural pastures without fertilizing should be noted. Supplementary feeding with rapeseed cake allowed to increase the pre-slaughter weight of purebred young animals by $12.4 \%$ (group II). The Khalkha-Suffolk crossbreed rams were superior to the purebred Khalkha in terms of the efficiency of pasture feed and supplementary feeding, which is due to the breed characteristics of one of the best English precocious breeds of Suffolk [3].

Studies on the feeding capacity and meat productivity of Khalkha sheep in the Kyakhtinskoye APO of the Republic of Buryatia, bordering the Selenginsky aimak of the 
MPR, showed that the young gelded rams at the age of 7 months after fattening on natural pastures reached a pre-slaughter live weight of $32.7 \mathrm{~kg}$ and at slaughter their carcass weight was $13.6 \mathrm{~kg}$. These data indicate the ability of sheep of this breed to effectively use the feed resources of dry-steppe pastures for the production of cheap young mutton [4]. The preslaughter weight of the crossbreeds was $31.7 \%$ higher than that of the purebred rams, compared with the peers of the second group and $48.0 \%$ of the first group (Table 1).

In our studies, there were differences in the weight of internal organs of purebred and crossbred animals. In purebred young animals, there is a tendency to exceed the development of some internal organs over half-breeds. Purebred young animals of the first and second groups, inferior to their half-blood peers in pre-slaughter weight by 1.5 and 1.3 times, respectively, tended to exceed them in heart weight by 0.03 and $0.04 \mathrm{~kg}$, liver - by 0.02 and $0.06 \mathrm{~kg}$ with almost the same spleen weight.

Table 1. Indicators of pre-slaughter and absolute weight of carcass, internal organs of young animals of experimental groups at the age of 8 months

\begin{tabular}{|l|c|c|c|}
\hline \multirow{2}{*}{\multicolumn{1}{|c|}{ Indicator }} & \multicolumn{3}{|c|}{ Group } \\
\cline { 2 - 4 } & I & II & III \\
\hline $\begin{array}{l}\text { Pre-slaughter live } \\
\text { weight, kg }\end{array}$ & $30.47 \pm 3.71$ & $34.25 \pm 3.42$ & $45.10 \pm 2.15$ \\
\hline $\begin{array}{l}\text { Carcass weight, } \\
\mathrm{kg}\end{array}$ & $13.5 \pm 2.52$ & $15.47 \pm 1.76$ & $21.16 \pm 1.90$ \\
\hline $\begin{array}{l}\text { Internal fat mass, } \\
\mathrm{kg}\end{array}$ & $0.91 \pm 0.01$ & $1.10 \pm 0.02$ & $1.00 \pm 0.03$ \\
\hline Liver & $0.50 \pm 0.03$ & $0.55 \pm 0.05$ & $0.48 \pm 0.11$ \\
\hline Kidney & $0.08 \pm 0.005$ & $0.08 \pm 0.004$ & $0.093 \pm 0.004$ \\
\hline Heart & $0.18 \pm 0.03$ & $0.19 \pm 0.02$ & $0.15 \pm 0.06$ \\
\hline Lungs & $0.34 \pm 0.01$ & $0.33 \pm 0.02$ & $0.52 \pm 0.07$ \\
\hline Spleen & $0.07 \pm 0.01$ & $0.08 \pm 0.00$ & $0.08 \pm 0.03$ \\
\hline Digestive system & $1.37 \pm 0.12$ & $1.64 \pm 0.10$ & $1.58 \pm 0.01$ \\
\hline
\end{tabular}

${ }^{*}$ Digestive system (GIT-Gastrointestinal track) - rumen, manifold, fore stomach, abomasum, small intestine, large intestine

Half-bred animals were inferior in absolute weight of the digestive system to purebred Khalkha rams of the second group by $0.06 \mathrm{~kg}$, which received rapeseed cake in addition to pasture feed during fattening; at the same time, they were superior in this indicator to rams of the first group of pasture management without supplement feeding by $0.21 \mathrm{~kg}$. These data indicate that supplement feeding with rapeseed cake contributes to an increase in the absolute weight of the digestive systems, which is due to the large consumption of feed. Purebred animals of the first and second groups were inferior to half-bred sheep in absolute lung weight by 0.18 and $0.19 \mathrm{~kg}$.

Differences between purebred Khalkha and half-bred Khalkha-Suffolk young animals in the development of the carcass, internal organs and digestive system were observed in relation to their pre-slaughter weight (Table 2).

Table 2. Relative development of the weight of carcass, internal organs and digestive system of young animals of experimental groups in $\%$ of the pre-slaughter weight

\begin{tabular}{|l|c|c|c|}
\hline \multirow{2}{*}{\multicolumn{1}{|c|}{ Indicator }} & \multicolumn{3}{|c|}{ Group } \\
\cline { 2 - 4 } & I & II & III \\
\hline Carcass weight, $\mathrm{kg}$ & 44.30 & 45.16 & 46.92 \\
\hline Internal fat mass, $\mathrm{kg}$ & 2.98 & 3.21 & 2.22 \\
\hline Liver & 1.64 & 1.60 & 1.06 \\
\hline
\end{tabular}




\begin{tabular}{|l|l|l|l|}
\hline Kidney & 0.26 & 0.23 & 0.21 \\
\hline Heart & 0.59 & 0.55 & 0.33 \\
\hline Lungs & 1.11 & 0.96 & 1.15 \\
\hline Spleen & 0.23 & 0.23 & 0.17 \\
\hline Digestive system $^{*}$ & 4.49 & 4.79 & 3.50 \\
\hline
\end{tabular}

${ }^{*}$ Digestive system (GIT-Gastrointestinal track) - rumen, manifold, fore stomach, abomasum, small intestine, large intestine

Half-bred Khalkha-Suffolk rams outperformed purebred Khalkha peers in relative carcass weight by 2.62 and $1.76 \%$ and lungs by 0.04 and $0.19 \%$. At the same time, they were inferior to purebred rams of the I and II experimental groups by weight of internal fat by 0.76 and $0.99 \%$, liver - by 0.58 and $0.54 \%$, kidneys - by 0.05 and $0.02 \%$, heart - by 0.26 and $0.22 \%$, spleen - by $0.06 \%$ and digestive system - by 0.99 and $1.29 \%$.

The better development of the heart, one of the main circulatory organs that carry out the metabolism in the animal's body, can be explained by the fact that the local breed was formed on pastures with sparse vegetation, as a result, the search for food by sheep is due to the greater intensity of their movement. According to V.A. Taishin and B.B. Lhasaranov (1997), native Buryat sheep, similar in origin to the Khalkha breed, in terms of motion activity in searching for food on the pasture, exceeded the Trans-Baikal fine-wooled sheep by 1.5 times [5]. At the same time, dry-steppe pasture food and dead grass contributed to a relatively better development of liver and gastrointestinal tract.

The greater development of the lungs in crossbreeds is probably due to the hereditary feature of the Suffolk breed, which was formed in the humid and relatively cool climate of England. These sheep and their crossbreeds, in contrast to the local coarse-haired and finewooled ones, are characterized by a slow metabolism and a phlegmatic temperament [6]. In conditions of dry climate and high temperature conditions, they react with increased respiration, which may lead to an increase in lungs weight. Specific breed characteristics are shown in terms of the ratio of organs weight to the live body weight. In our experiment, crossbred animals had a lower ratio of the weight of liver, heart, spleen, and digestive system to the pre-slaughter weight than purebred animals.

The absolute weight of most organs depends on the feeding conditions [7]. In the experiment, the positive dependence of additional supplement feeding with an increase in the weight of liver and digestive system was confirmed.

B. Minzhigdorzh (1996) found that the ram of Khalkha breed with feeding on natural pastures at the age of eight months, had a pre-slaughter weight of $34.6 \mathrm{~kg}$, of which the internal organs accounted for: $0.42 \%$ - heart; $0.8 \%$ - lungs; $1.5 \%$ - liver; $0.23 \%$ - spleen; $0.23 \%$ - kidneys; $4.1 \%$ - digestive system [8].

\section{Conclusion}

Young sheep of the Khalkha breed had satisfactory meat conditions when grazing on drysteppe pastures without rapeseed cake supplement feeding. By the end of fattening at the age of 8 months after one-day fasting, the pre-slaughter weight of the rams was $30.47 \mathrm{~kg}$ and the carcass weight was $13.5 \mathrm{~kg}$.

With supplement feeding of purebred young animals in addition to pasture feed with rapeseed cake ad libitum, the pre-slaughter weight increased to $34.25 \mathrm{~kg}$, and the carcass weight increased to $15.47 \mathrm{~kg}$, or by 12.4 and $14.6 \%$.

One of the methods of increasing the meat earliness of young Khalkha animals can be used in crossing of the gene pool of sheep of the specialized meat breed Suffolk with them. Half-bred Khalkha-Suffolk lambs were born larger and, when fattening on natural pastures 
with rapeseed cake, grew more intensively in comparison with purebred peers of the Khalkha breed. Young animals at slaughter after fattening at the age of 8 months had a preslaughter weight of $45.1 \mathrm{~kg}$ and a carcass weight of $21.16 \mathrm{~kg}$.

According to these indicators, crossbreed young animals were superior to their peers of the Khalkha breed, who received rapeseed cake in addition to pasture grass, in terms of preslaughter and carcass weight by 31.68 and $31.78 \%$. At the same time, both the absolute and relative development of the carcass and internal organs of purebred and half-bred young animals was mainly influenced by the heredity of the Khalkha and Suffolk sheep, which differed in their external and constitutional characteristics and adaptive capabilities for separation in areas with specific climatic and feeding conditions.

Mongolian sheep tolerate the dry and sharply continental climate of the Central Asia well. Their main food is low-growing, sparse vegetation of dry steppes, deserts and piedmont hills. When grazing, they show increased motion activity associated with the search for plants with the best feed qualities [5].

Suffolk sheep belong to the Down group of meat breeds, common on the low plains of the Central and Southern England, characterized by a moderately warm and humid climate, favorable for plant vegetation. Sheep are kept in seeded fenced pastures, mainly of legumegrass mixtures. With a high yield of grass, sheep of meat breeds lose less feed energy for movement and use it more effectively for muscle tissue growth. Studies have found that the energy requirement of grazing sheep to maintain life is $10-25 \%$ higher than when they are kept indoors. In poor grazing conditions, this indicator will increase to $100 \%[10,11,12]$.

In the sheep farming of the hilly zone, in the North of England with a slightly different technology of grazing animals, Down breed sheeps are used only in crossing with local Scottish black-headed and Welsh ewes in order to obtain fattening lambs with a high intensity of weight gain during the growing period.

In half-bred young animals from Suffolk sheeps for 160 days of cultivation, the average daily increase was $238 \mathrm{~g}$ (A.U. Spidis, 1983). In our studies (8), the average daily increase in the raising period from 1.5 to 3 months was $197.1 \mathrm{~g}$, and from 3 to 8 months $-192.4 \mathrm{~g}$. The obtained data allow to come to the conclusion about the feasibility of using the gene pool of the early meat breed Suffolk in crossing with local sheeps of Mongolia to obtain fattening lambs with high growth intensity and meat productivity

\section{References}

1. D. Byamba, S.I. Biltuev, Bulletin of the BSAA, 3, 19-25 (2017)

2. A.A. Veniaminov, S.V. Buylov, R.S. Khamishchaev, Study of sheep meat productivity (VIZh. M., 45, 1978)

3. A.U. Spidy, Sheep farming, Nauka-practike (M, 167-185, 1988)

4. S.I. Biltuev, V.A. Achituev, B.V. Zhamyanov, IOP Conference Series Earth and Environmental Science, 395, 012115, (2019) DOI:10.1088/1755-1315/395/1/012115

5. V.A. Tayshin, B.B. Lhasaranov, Aboriginal Buryat sheep (Ulan-Ude, 124, 1997)

6. A.I. Erokhin, S.A. Erokhin, Constitution of sheep (Textbook Sheep Breeding, M. 2024, 2004)

7. M.K. Kroyter, Genetic and breeding aspects of crossbred sheep breeding (Nauka, Alma-Ata, 298,1977)

8. B. Minzhigdorzh, Theoretical and methodological basis of Mongolian sheep breeding, Doctor of Science dissertation, Ulaanbaatar, (1996).

9. L. Shimit, S. Biltuev, V. Achituev, B. Zhamyanov, Z. Mongush, E3S Web of Conferences 176, 01009 (2020) 
10. Y.W. Arnold et. ul. Agric. Anim. Husb., 5, 396 (1965)

11. Lambourne H.I. Proc. New-Zesz. probe. Paster Nankvoen., 21, 92 (1960)

12. Lambourne H.I., Reardon T.F. Austr. Joun. Agric. Res., 21, 92 (1963)

13. http://www.fao.org/3/y5019e07.htm

14. https://opendata. $1212 . \mathrm{mn} / \mathrm{mn} / \mathrm{doc}$ 